\title{
Writing Descriptive Essays Using ‘the Tree Diagram’ as a Tool
}

\author{
Gopala Krishnan Sekharan Nair ${ }^{1}$, Rozlan Abdul Rahim ${ }^{1}$, Roszainora Setia ${ }^{1}$, Aileen Farida binti Mohd Adam ${ }^{1}$, \\ Norhayati Husin ${ }^{1}$, Elangkeeran Sabapathy ${ }^{1}$, Razita Mohamad ${ }^{1}$, Shahidatul Maslina Mat So'od ${ }^{1}$, Nurul Izatee Md \\ Yusoff $^{1}$, Razifa Mohd Razlan ${ }^{1}$, Nur Amalia Abd Jalil ${ }^{1}$, Ab. Aziz Husain ${ }^{2} \&$ Norhafiza Abu Seman ${ }^{3}$ \\ ${ }^{1}$ Academy of Language Studies, Universiti Teknologi MARA (UiTM), Dungun, Malaysia \\ ${ }^{2}$ Rantau Panjang Secondary School, Rantau Panjang, Malaysia \\ ${ }^{3}$ Faculty of Administrative Science and Policy Studies, Universiti Teknologi MARA (UiTM), Dungun, Malaysia \\ Correspondence: Gopala Krishnan Sekharan Nair, Academy of Language Studies, Universiti Teknologi MARA \\ (UiTM), Dungun Campus, 23000 Dungun, Malaysia. Tel: 60-9-8400-8225/60-12-900-2602. E-mail: \\ gopal792@tganu.uitm.edu.my
}

Received: December 29, $2011 \quad$ Accepted: February 14, $2012 \quad$ Published: June 1, 2012

doi:10.5539/ass.v8n7p40

URL: http://dx.doi.org/10.5539/ass.v8n7p40

\begin{abstract}
The study is experimental in nature. Both the experimental group and the control group comprised respondents who are sixth form students of SMK Rantau Panjang, Kelantan. The experimental group was exposed to the 'tree-diagram' writing strategy for a period of one month. This meant a total exposure of sixteen 40-minute periods for the duration of the month. Both the groups were subjected to a pre-test at the onset of the experiment and a post test one month later. A t-test showed that there was a significant difference between the pre test and the post test writing marks of the experimental group whereas no such significant difference was found in the control group. A similar t-test showed that there was a significant difference in the grammar scores of the experimental group but none for the control group. There was also a significant difference between the pre test and post test motivation score of the experimental group. However, a t-test indicated that there was no significant difference in the motivational scores of the males and females at the conclusion at the experimental period. Future researchers should focus on the use of tree-diagram to assist other types of essays such as argumentative essays.
\end{abstract}

Keywords: tree-diagram, writing strategy, motivation level, descriptive essay, writing skills

\section{Introduction}

English has become more and more important since the advent of IT. Indeed for Malaysia, English language has also become a matter of economic survival. The government has always been aware that it is unsafe for the country to depend entirely on its non-replenishable commodity for its economic survival. In the last decade, there has been a lot of emphasis on the creation of knowledge economy or K-economy. The K-economy is an economy where the most valuable resource will be the highly trained human resource. The government has made efforts towards this direction. To build up the K-economy and expand the knowledge of the human resource, English is a vital asset.

Throughout the last decade, the ministry of education Malaysia has been trying various means of upgrading the proficiency level of the students so that they will leave the education system with the satisfactory command of English. There is a need for improving the English so that the nation is not left behind in the era of globalization. There is universal agreement that English is the key to a lot of higher knowledge on Science and technology. This is further compounded by the fact that the language of IT is English.

In Malaysia, students are required to take the Malaysian University English Test (MUET) as a prerequisite to university entry. An analysis of the MUET scores indicated that, the writing component posed problems to many students. This is not surprising as according to Ikeguchi and Cecelia (1997), the productive skills such as writing are more difficult than the receptive skills of listening and reading. In this study, the 'tree-diagram' strategy was found to have improved coherency and the grammar in writing. It was further found to have boosted students' morale and reduced their aversion to writing.

This study tried the 'tree-diagram' strategy in an effort to find a suitable strategy which would improve the writing of the students. This study focuses only the writing skill, which is the most difficult of all language skill. An 
experiment is carried out to find out whether the use of a writing strategy such as the 'tree-diagram' can make writing less painless.

\section{Literature Review}

Writing Skills: According to Nunan, (1998), writing is both a process and a product.

Descriptive Writing: According to Jacobs and George (1986), description is a mode of expository writing which is relied upon in other expository modes.

Writing Strategy And The 'Tree-Diagram': This is a strategy for writing. It utilizes a diagram which has branch-like subdivisions. The diagram was developed by Chien and Ching, (2004) from the Nanyang Technological University in Singapore who adopted it from the text book "Refining Composition Skills" by Smalley, Ruetten \& Kozyrev (2001), and is shown in Figure 1.

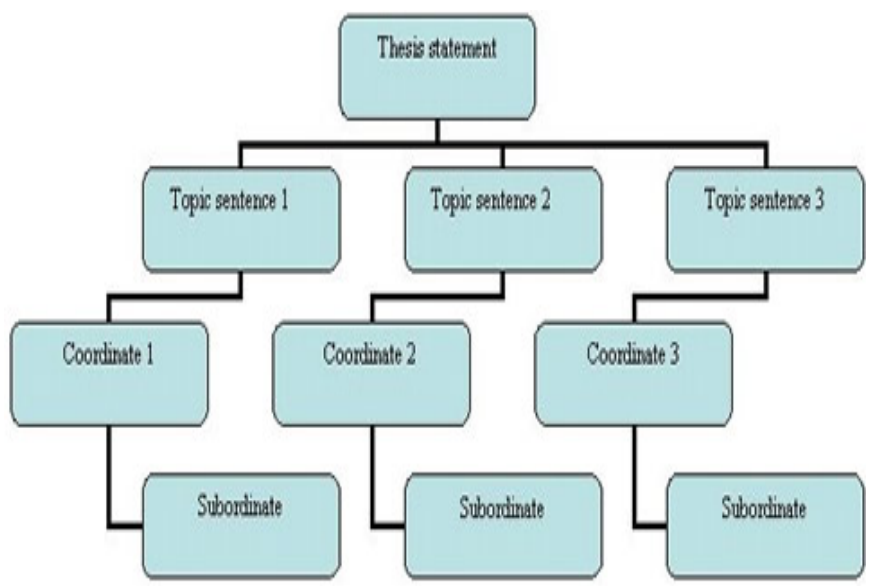

Figure 1. The “tree-diagram' developed by Chien, Ching L. in 2004

Novice writers do not have the propensity to plan paragraphs or essays as a whole formally or informally Stallard (1974). Scardamalia \& Bereiter (1986), said that they use the trial-and-error approach to trigger more writing and if they get stuck in their writing, they will just start all over again using another word in the topic that they can relate to and tell about. They also spend little time planning and start off writing although they are still confused about the task Richards (1990). Their main aim is to detect and fix errors rather than rethink their composition Perl (1979).

The Tree Diagram method was found to be very suitable for form six students. Many form 6 students who are going to sit for MUET still write incomprehensibly. Previously, when students write before first representing their ideas in graphic form, they appear to be making various mistakes. They are writing paragraphs without any topic sentence. There is no controlling idea in the topic sentence and this is reflected in their elaboration which is not focused. Students also found it difficult to write the thesis statement. This may be because they are still thinking at paragraph level. Grammar improves when the writer is more concerned with conveying meaning rather than being inhibited by thinking of the language and words.

The students appear to get excited when given the 'tree-diagram'. They get the feeling that, they have been given a tool to manage a task. Cabrera and Bazo (2004), while acknowledging the effectiveness of graphic representation as an essay writing tool, did advise teachers to be selective in the use of strategy. According to Gardner (1987), perhaps the most remarkable difference between competent and incompetent writers is that those who are less successful are not strategic. The writers see writing as something formidable when not using any strategy.

Cimcoz (1999), stated that most students thought that writing is boring and therefore develop an aversion to writing and find diagrammatic approaches useful. Scott (1996), cited in Aloha and Steven (2002), also urged the teaching of writing strategies, they stressed that teachers need to help students develop effective strategies for each phase of writing process. Massi. Maria. P (1997) believes that the use of diagrammatic maps makes writing appear more cognitive and concrete thereby appealing to a broad spectrum of novice writers.

\section{Methodology}

This study is experimental in nature. A treatment variable, namely a writing strategy such as the 'tree-diagram' was being introduced to the experimental group over a period of 1 month. This meant, exposure to sixteen 40-minute periods during which the experimental group was exposed to the 'tree-diagram' writing strategy. 
Population and Sample: The population for this study will be the form six students of four form six classes in SMK Rantau Panjang, Kelantan, Malaysia. One class of 30 students, namely 6R1 will be taken as the experimental group while the 30 students of 6R2 will form the control group. Only the experimental group will be exposed to the tree-diagram. Pre-tests and post-tests will be given to both groups before and after treatment.

Instrumentation: A Likert Scale questionnaire will be used to collect data in addition to the pre-tests and post-tests. The questionnaire will be used to measure motivation scores.

\section{Results and Discussion}

\subsection{Answering Research Questions}

Research Questions 1: Is there any significant difference in the descriptive essay writing performance of the students due to the use of writing strategy such as the 'tree diagram' method?

Table 1. The pre-test and post-test writing scores

\begin{tabular}{llll}
\hline Group & $\mathrm{N}$ & & Mean \\
\hline & & Pre- test & Post- test \\
Experimental & 30 & 45.80 & 50.40 \\
Control & 30 & 43.47 & 41.00 \\
\hline
\end{tabular}

Table 1 shows the mean of the pre-test and post-test writing scores of both the experimental and control group.

Table 2. Comparing the means of the pre-test and post-test scores

\begin{tabular}{cccc}
\hline & $\mathrm{t}$ & $\mathrm{df}$ & Sig. (2-tailed) \\
\hline Experimental group & -6.986 & 29 & .000 \\
Control group & 1.165 & 29 & .253 \\
\hline
\end{tabular}

Table 1 and 2 are used to answer research question 1. The pre-test mean of the overall writing score, of the experimental group is 45.80 while the mean of the post-test is 50.40 . Whereas for the control group, the pre-test mean is 43.47 and the post-test mean is 41.00 as shown in table 1 .

The t-testing in table 2 showed that this means that there is no significant difference between the pre-test and post-test means of the control group but there exists a significant difference between the pre-test and post-test mean of the experimental group.

It is clear that the use of strategy in writing gives students the feeling that they are properly armed to tackle writing end up producing writing pieces with better style and grammar.

Research Question 2: Is there a significant difference in the grammar score of the students due to the use of writing strategy such as the 'tree-diagram' method?

Table 3. The pre-test and post-test grammar score

\begin{tabular}{lllc}
\hline Group & N & Mean & \\
& & Pre- test & Post- test \\
Experimental & 30 & 5.80 & 7.97 \\
Control & 30 & 5.80 & 5.77 \\
\hline Table 4. Comparing the means of the pre-test and post-test scores & & Sig. (2-tailed) \\
\hline \multicolumn{2}{c}{$\mathrm{T}$} & 29 & .000 \\
\hline Experimental group & -9.842 & 29 & .879
\end{tabular}

Table 3 and 4 are used to answer research question 2. Table 3 shows the mean scores. The t-test in table 4 showed that there is significant difference between the pre-test and post-test means of the experimental group but no such difference in the control group. 
This leads the researcher to conclude that the introduction of writing strategy, such as the 'tree-diagram' does produce a significant difference in the grammar of students' essay, when strategies are employed in writing, confidence replaces inhibitions. There is no fear of writing and the ideas flow out systematically leading to better structured sentences as the writer is eager to convey his message.

Research Question 3: Is there a significant difference between the motivation level of the male and female students in the experimental group at the conclusion of the one-month experimental period?

Table 5. Motivation score of experimental group

\begin{tabular}{lllll}
\hline Group & $\mathrm{N}$ & & Mean & \\
\hline & Male & Female & Male & Female \\
Experimental & 14 & 16 & 37.36 & 35.75 \\
\hline
\end{tabular}

Table 6. Comparing the means of motivation score of males and females

\begin{tabular}{ccc}
\hline $\mathrm{t}$ & $\mathrm{df}$ & Sig. (2-tailed) \\
\hline-.810 & 28 & .425 \\
-.807 & 26.922 & .427
\end{tabular}

Table 5 shows the means of the motivation levels of the males and females in the experimental group. Table 6 shows that there is no significant difference between the means of motivation scores of the males and females. This means that, the treatment variable, namely, the introduction of the 'tree-diagram' has produced equally beneficial results on both males and females. In terms of choice of pedagogy, this finding may be useful.

Research Question 4: Is there a significant difference between the motivation level towards writing of the experimental group before and after the duration of the experiment?

Table 7. Motivation means of the experimental group

\begin{tabular}{lllll}
\hline & Mean & N & Std. Deviation & Std. Error Mean \\
\hline $\begin{array}{l}\text { Pos- Motivation } \\
\text { Score }\end{array}$ & 36.5000 & 30 & 5.38677 & .98348 \\
$\begin{array}{l}\text { Pre-Motivation } \\
\text { Score }\end{array}$ & 23.7000 & 30 & 3.29210 & .60105 \\
\hline
\end{tabular}

Table 8. Comparing the means of the motivation scores

\begin{tabular}{ccc}
\hline $\mathrm{t}$ & $\mathrm{df}$ & Sig. (2-tailed) \\
\hline 10.57 & 29 & .000
\end{tabular}

Table 7 shows the motivation scores of the experimental group before and after the experiment. Table 8 shows the t-test results of the comparison of the two means. There is a significant difference between the means of the motivation level, before and after the duration of the experiment.

\section{Conclusion}

In conclusion, this study shows that the 'tree-diagram' not only improves the overall writing score and the learners' grammar in writing, but it also motivates the learners. The learners' aversion to writing is removed and they do not come to regard writing as a painless and tedious chore. The findings are backed by sufficient literature review from previous researches.

In view of the above, there should be more widespread implementation of the 'tree-diagram' in the classroom. Teacher Training Institutes should introduce the 'tree-diagram' to trainees as pedagogy in the teaching of writing. Courses can be held for existing teachers in schools to familiarize them with the 'tree-diagram'.

\section{References}

Aloha, Steven K. (2002). Writing with style: Two Useful Strategies for Students. Retrieved October 21, 2005, from http://www.iteslj.org/ 
Cabrera, \& Bazo. (2004). Teaching the Four Skills in the Primary EFL Classroom. Retrieved October 24, 2005, from http://www.iteslj.org/

Chien, Ching L. (2004). Seeing Is Understanding: Improving Coherence in Students Writing. Retrieved October 10, 2005, from http://www.iteslj.org/

Cimcoz, Y. (1999). Teaching ESL/EFL Students to Write Better. Retrieved October 10, 2005, from http://www.iteslj.org/

Gardner. (1987). Teaching of Writing in an ESL Context. Rowley: Newburn House.

Ikeguchi, Cecelia B. (1997). Teaching Intergrated Writing Skills. International Journals for Teachers of writing Skills. Retrieved from http://iteslj.org

Jacobs, George. (1986, October). Quickwriting: a technique for invention in writing. ELT Journal, 40(4), 282-290. http://dx.doi.org/10.1093/elt/40.4.282

Massi. Maria. P. (1997). Interactive writing in the EFL class: A Repoitare of Tasks. Retrieved October 10, 2005, from http://uteslj.org

Nunan, D. (1998). The Learner-centered Curriculum. Cambridge: Cambridge University Press.

Perl, S. (1979). The composing processes of unskilled college writers. Research in the Teaching of English, 13(4), 317-336.

Richards, J.C. (1990). The Language Teaching Matrix. Cambridge: Cambridge University Press. http://dx.doi.org/10.1017/CBO9780511667152

Scardamalia, M., \& Bereiter, C. (1986). Research on written composition. Handbook of Research on Teaching.

Scott, V. M. (1996). Rethinking Foreign Language Writing. Boston, M.A.: Heinle \& Heinle.

Smalley, R. L., Ruetten, M. K., \& Kozyrev, J. R. (2001). Refining Composition Skills (5th ed.). Boston: Heinle \& Heinle.

Stallard, C.K. (1974). An analysis of the writing behaviour of good student writers. Research in the Teaching of English, 8(2), 206-218. 